\title{
Description of strain 3CB-1, a genomovar of Thauera aromatica, capable of degrading 3-chlorobenzoate coupled to nitrate reduction
}

\author{
Bongkeun Song, Norberto J. Palleroni and Max M. Häggblom
}

Department of Biochemistry and Microbiology and Biotechnology Center for Agriculture and the Environment, Cook College, Rutgers University, New Brunswick, NJ 08901-8525, USA
Author for correspondence: Max M. Häggblom. Tel: +1 7329329763 ext. 326. Fax: +1 7329328965. e-mail: haggblom@aesop.rutgers.edu

\begin{abstract}
A Gram-negative bacterium, strain 3CB-1, isolated from a 3-chlorobenzoate enrichment culture inoculated with a sediment sample is capable of degrading various aromatic compounds and halogenated derivatives with nitrate as electron acceptor. Compounds capable of serving as carbon and energy sources include 3-chlorobenzoate, 3-bromobenzoate, 2-fluorobenzoate, 4-fluorobenzoate, benzoate, 3-hydroxybenzoate, 4-hydroxybenzoate, 3-aminobenzoate, protocatechuate, $m$-cresol and $p$-cresol. Oxygen, nitrate and nitrite were used as electron acceptors for growth. Cells are Gram-negative short rods with peritrichous flagellation. The predominant fatty acids are cis-9-hexadecenoic acid $(16: 1 \omega 7 c)$, hexadecanoic acid $(16: 0)$, octadecanoic acid (18:0), octadecenoic acid (18:1), 3-hydroxydecanoic acid (10:0 30H) and dodecanoic acid (12:0). The sequence of the 16S rRNA gene, as well as the fatty acid composition, indicate that the strain is a member of the genus Thauera in the $\beta$-subclass of the Proteobacteria and very close to Thauera aromatica. DNA-DNA hybridization and nutrient screening indicate that strain 3CB-1 is a genomovar of Thauera aromatica with the proposed name Thauera aromatica genomovar chlorobenzoica.
\end{abstract}

Keywords: Thauera aromatica genomovar chlorobenzoica, nitrate reduction, 3-chlorobenzoate degradation

\section{INTRODUCTION}

The anaerobic degradation of chlorobenzoates has been studied under various conditions, with nitrate, iron(III), sulfate or carbonate as terminal electron acceptors (Häggblom et al., 1993; Kazumi et al., 1995). Chlorobenzoates are also degraded anaerobically by phototrophic bacteria Rhodopseudomonas palustris strains WS17 and DCP3 in the presence of light (Kamal \& Wyndham, 1990; van der Woude et al., 1994). Anaerobic mineralization of 3- and 4-chlorobenzoate has been observed in various sediment and soil samples with concomitant nitrate reduction (Häggblom et al., 1993, 1996). Strain 3CB-1 was isolated from an enrichment culture carried out under these conditions (Häggblom \& Young, 1999) and the purpose of this communication is to describe this organism and to determine its phylogenetic relationships to known taxa.

The GenBank accession number for the $16 \mathrm{~S}$ rDNA sequence of strain 3CB-1 is AF123264.
Preliminary studies on strain 3CB-1 suggested that it was related to the Thauera-Azoarcus group in the $\beta$ subclass of the Proteobacteria. The type species of the genus Thauera is Thauera selenatis, which is capable of selenate and nitrate respiration (Macy et al., 1993). Other species of Thauera have since been described under the names Thauera aromatica, Thauera linaloolentis and Thauera terpenica (Anders et al., 1995; Foss \& Harder, 1998). Studies on T. aromatica strains $\mathrm{K} 172^{\mathrm{T}}$ and $\mathrm{T} 1$ suggested modifications of the genus definition, which eventually underwent two amendments, one of which pertained to physiological properties (Anders et al., 1995) and the other to the flagellation of the cells (Song et al., 1998).

Three strains of $T$. aromatica have been extensively studied. These are strain $\mathrm{K} 172^{\mathrm{T}}$, the type strain of the species (Anders et al., 1995), strain AR-1, capable of degrading $\alpha$-resorcylate with nitrate as electron acceptor (Gallus et al., 1997), and strain T1, which, as strain $\mathrm{K} 172^{\mathrm{T}}$, was examined for its capacity for toluene degradation coupled to nitrate reduction (Evans et al., 1991; Song et al., 1998). T. linaloolentis and 
(a)

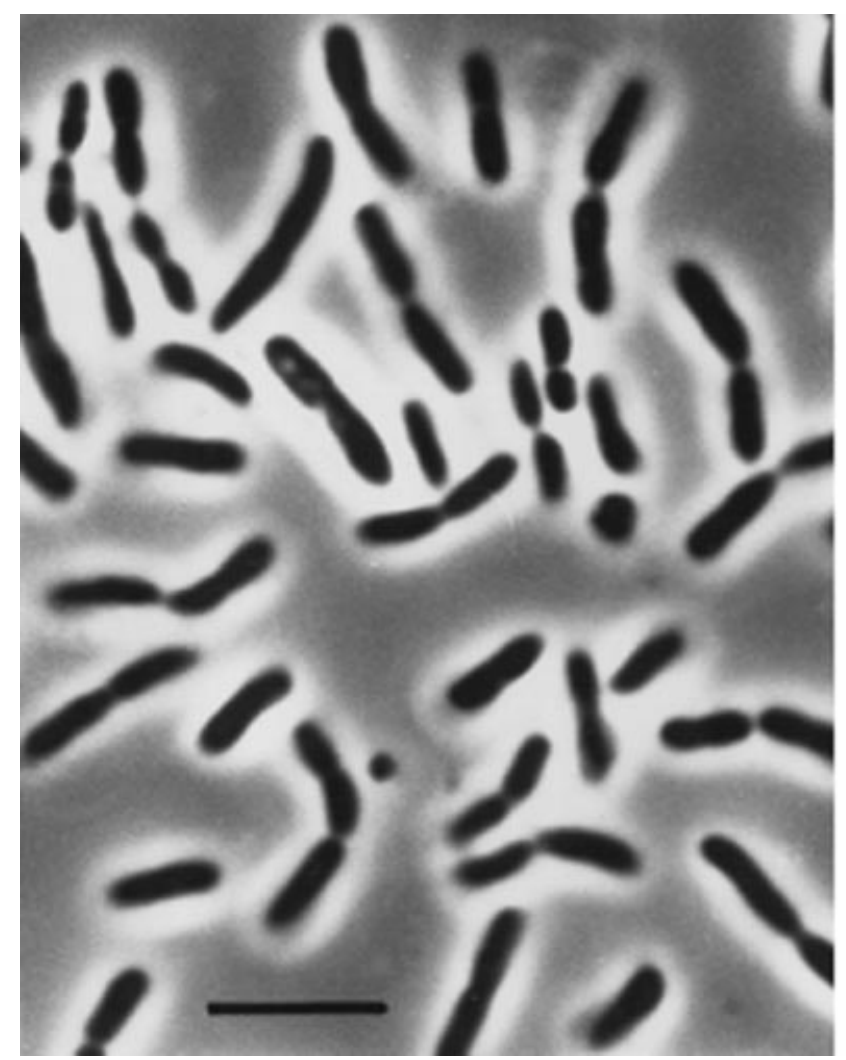

(b)
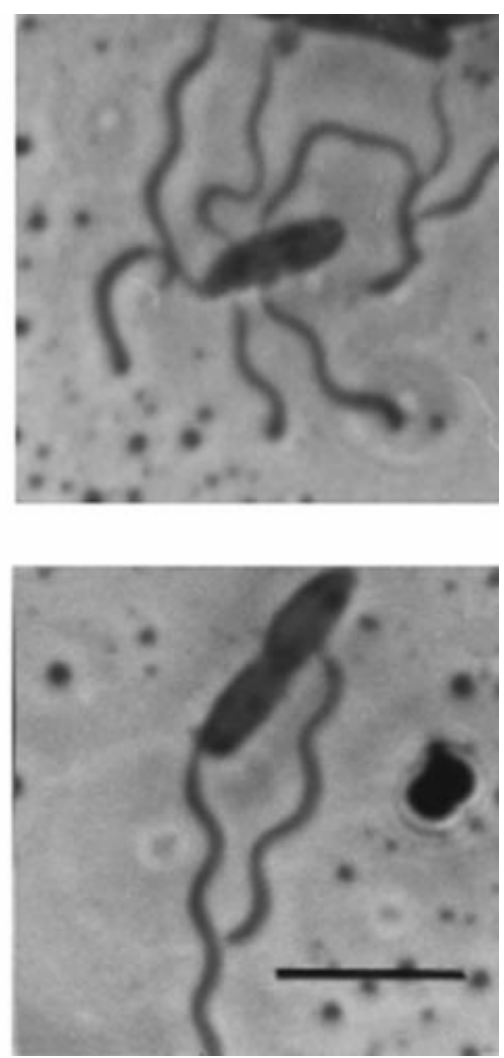

Fig. 1. (a) Phase-contrast micrograph and (b) flagella preparation (Leifson stain) of cells of strain 3 CB-1. Cells were grown on M-R2A for 24 h. Bars, $5 \mu \mathrm{m}$.

T. terpenica are of interest because of their capacity to degrade linalool (strain $47 \mathrm{Lol}^{\mathrm{T}}$ ) and monoterpenes (strains $21 \mathrm{Mol}$ and $58 \mathrm{Eu}^{\mathrm{T}}$ ), respectively (Foss \& Harder, 1998).

We propose to add strain 3CB-1 to Thauera aromatica as a genomovar, Thauera aromatica genomovar chlorobenzoica, on the basis of a polyphasic analysis.

\section{METHODS}

Bacterial strains and growth conditions. Strain $3 \mathrm{CB}-1$ was isolated from a 3-chlorobenzoate-degrading denitrifying enrichment culture inoculated with sediment from the Hudson River near Albany, NY, USA. (Häggblom \& Young, 1999). Strain 3CB-1 (ATCC 700723), and $T$. aromatica strains $\mathrm{K} 172^{\mathrm{T}}$ (DSM $6984^{\mathrm{T}}$ ) and T1 (ATCC 700265) were anaerobically cultivated in a minimal salts medium (Tschech \& Fuchs, 1987) with succinate as carbon source and nitrate as electron acceptor. T. selenatis strain $\mathrm{AX}^{\mathrm{T}}$ (ATCC 55363 ${ }^{\mathrm{T}}$ ) was grown in a vitamin-amended medium (Macy et al., 1993). Azoarcus tolulyticus strain Tol4 $^{\mathrm{T}}$ (ATCC $51758^{\mathrm{T}}$ ), Azoarcus evansii strain $\mathrm{KB} 740^{\mathrm{T}}$ (DSM 6898 ${ }^{\mathrm{T}}$ ), Azoarcus toluclasticus strain MF63 ${ }^{\mathrm{T}}$ (ATCC $700605^{\mathrm{T}}$ ), Azoarcus toluvorans strain Td21 ${ }^{\mathrm{T}}$ (ATCC $700604^{\mathrm{T}}$ ) and Azoarcus indigens strain VB32 ${ }^{\mathrm{T}}$ (LMG 9092 ${ }^{\mathrm{T}}$ ) were grown on M-R2A medium as described previously (Song et al., 1999).
Morphological and physiological characterization. Cell dimensions and morphology were examined by phasecontrast microscopy. Flagella were stained using the method of Leifson (1951). Flagellation of strains of T. linaloolentis (DSM 12138) and T. terpenica (DSM 12139 and DSM 12140) was also determined. The presence of catalase and oxidase was tested as described elsewhere by Smibert \& Krieg (1994). Growth on nutrient, brain-heart infusion and trypticase soy agar plates was tested at $30{ }^{\circ} \mathrm{C}$ under aerobic conditions. Salt tolerance was tested under denitrifying conditions in liquid medium (Tschech \& Fuchs, 1987) containing 2 or $5 \% \mathrm{NaCl}$ at $30{ }^{\circ} \mathrm{C}$. Hydrolysis of gelatin and starch, and the presence of urease were determined by the methods of Smibert \& Krieg (1994). The optimum temperature for growth of cells was tested at $4,10,30$ and $37^{\circ} \mathrm{C}$ and the optimum $\mathrm{pH}$ for growth was tested at $\mathrm{pH} 6,7,7 \cdot 5$, 8 and $8 \cdot 5$.

The utilization of aromatic compounds (all compounds purchased from Aldrich; minimum 97\% purity) was tested by using a dense cell suspension of strain 3CB-1 and substrates at a concentration of $100 \mu \mathrm{M}$ under aerobic and denitrifying conditions. Growth on different compounds was also tested with $1 \mathrm{mM}$ substrates on agar plates (Tschech \& Fuchs, 1987) under aerobic and denitrifying conditions. Growth of strain 3CB-1 with alternative electron acceptors (10 mM NO $\mathrm{m}_{3}^{-}, \mathrm{NO}_{2}^{-}, \mathrm{SO}_{4}^{2-}, \mathrm{SO}_{3}^{2-}, \mathrm{S}_{2} \mathrm{O}_{3}^{2-}, \mathrm{SeO}_{4}^{2-}$ or $\mathrm{SeO}_{3}^{-}$, or in 
Table 1. Characteristics of strain $3 C B-1$ and members of the genus Thauera

\begin{tabular}{|c|c|c|c|c|c|c|}
\hline Characteristic & Strain 3CB-1 & $\begin{array}{c}T \text {. aromatica } \\
\mathrm{K}_{172^{\mathrm{T}} *}\end{array}$ & $\begin{array}{c}T . \text { aromatica } \\
\mathrm{T} 1 \dagger\end{array}$ & $\begin{array}{c}T . \text { selenatis } \\
\mathrm{AX}^{\mathrm{T}}+\end{array}$ & $\begin{array}{l}\text { T. linaloolentis } \\
\text { 47 } \mathrm{Lol}^{\mathrm{T}} \S\end{array}$ & $\begin{array}{c}T . \text { terpenica } \\
\text { 58Eu }{ }^{\mathrm{T}} \S\end{array}$ \\
\hline Cell morphology & Rods & Coccoid rods & Rods & Rods & Rods & Rods \\
\hline Cell size $(\mu \mathrm{m})$ & $3 \cdot 0 \sim 3 \cdot 7$ & $1 \cdot 0 \sim 2 \cdot 5$ & $2 \cdot 5 \sim 3.0$ & $1 \cdot 4$ & $1.4 \sim 2.7$ & $1 \cdot 6 \sim 2 \cdot 2$ \\
\hline Motility & + & + & + & + & - & + \\
\hline Flagellation & Peritrichous & Peritrichous & Peritrichous & Monotrichous & None & Monotrichous \\
\hline Catalase and oxidase & + & + & + & + & + & + \\
\hline $\mathrm{G}+\mathrm{C}$ content $(\mathrm{mol} \%)$ & $68 \cdot 6$ & 67 & 66 & 66 & $65 \cdot 6$ & $64 \cdot 2$ \\
\hline Optimum $\mathrm{pH}$ for growth & $7 \cdot 5-8 \cdot 0$ & $7 \cdot 0-7 \cdot 4$ & $7 \cdot 5-8 \cdot 0$ & $8 \cdot 0$ & $7 \cdot 0-7 \cdot 3$ & $7 \cdot 9-8 \cdot 8$ \\
\hline $\begin{array}{l}\text { Optimum temperature for } \\
\text { growth }\left({ }^{\circ} \mathrm{C}\right)\end{array}$ & 30 & 28 & $\mathrm{ND}$ & $25-30$ & 32 & 32 \\
\hline Electron acceptors & $\mathrm{NO}_{3}^{-}, \mathrm{O}_{2}$ & $\mathrm{NO}_{3}^{-}, \mathrm{O}_{2}$ & $\mathrm{NO}_{3}^{-}, \mathrm{O}_{2}$ & $\begin{array}{c}\mathrm{NO}_{3}^{-}, \mathrm{O}_{2} \\
\mathrm{Se}(\mathrm{VI}), \mathrm{Se}(\mathrm{IV})\end{array}$ & $\mathrm{NO}_{3}^{-}, \mathrm{O}_{2}$ & $\mathrm{NO}_{3}^{-}, \mathrm{O}_{2}$ \\
\hline \multirow[t]{2}{*}{ Sole carbon substrate } & \multicolumn{6}{|c|}{ Growth under aerobic or denitrifying conditions $\|$} \\
\hline & $\mathrm{O}_{2} / \mathrm{NO}_{3}^{-}$ & $\mathrm{O}_{2} / \mathrm{NO}_{3}^{-}$ & $\mathrm{O}_{2} / \mathrm{NO}_{3}^{-}$ & $\mathrm{O}_{2}$ & $\mathrm{NO}_{3}^{-}$ & $\mathrm{NO}_{3}^{-}$ \\
\hline Benzoate & $+/+$ & $+/+$ & $+/+$ & + & - & - \\
\hline Benzyl alcohol & $-/+$ & $-/-$ & $-/-$ & ND & ND & ND \\
\hline Caproate & $-/+$ & $-/-$ & $-/-$ & ND & ND & ND \\
\hline Glucose & $-/-$ & $-/-$ & $-/-$ & \pm & - & - \\
\hline 2-Hydroxybenzoate & $-/-$ & $-/ \pm$ & $-/-$ & ND & ND & ND \\
\hline 3-Hydroxybenzoate & $+/+$ & $+/+$ & $+/+$ & ND & ND & ND \\
\hline 4-Hydroxybenzoate & $+/+$ & $+/+$ & $+/+$ & ND & ND & ND \\
\hline 4-Hydroxyphenylacetate & $-/-$ & $+/+$ & $+/+$ & ND & ND & ND \\
\hline Phthalate & $-/-$ & $-1-$ & $-/-$ & ND & ND & ND \\
\hline Propionate & $-/-$ & $+/+$ & $+/+$ & + & + & + \\
\hline Toluene & $-/-$ & $-1+$ & $-1+$ & ND & - & - \\
\hline
\end{tabular}

ND, Not determined.

* Data obtained from Anders et al. (1995).

$\dagger$ Data obtained from Song et al. (1999).

f Data obtained from Macy et al. (1993).

$\S$ Data obtained from Foss \& Harder (1998).

$\|+$, Growth; - , no growth.

the presence of oxygen) was tested using succinate as carbon source.

Determination of cellular fatty acids. Strain 3CB-1, strains of the genera Azoarcus and Thauera, and Pseudomonas stutzeri type strain ATCC $17588^{\mathrm{T}}$ were grown with $10 \mathrm{mM}$ succinate and $30 \mathrm{mM}$ nitrate under anaerobic conditions for $24 \mathrm{~h}$ as described previously (Song et al., 1999). T. selenatis $\mathrm{AX}^{\mathrm{T}}$ was cultivated with the same medium with the addition of a fivefold higher concentration of vitamins. Cells were harvested by centrifugation and the cellular fatty acid composition was determined by GC following the procedures of the Sherlock Microbial Identification System (MIDI Inc.).

To observe changes in the fatty acid profile of strain 3CB-1 during growth, cells were cultivated with $10 \mathrm{mM}$ succinate and $30 \mathrm{mM}$ nitrate in liquid medium and harvested after different incubation periods.

Isolation of genomic DNA and determination of DNA base composition. Genomic DNA was isolated and purified as described previously (Song et al., 1998). The DNA base composition of strain 3CB-1 was determined by HPLC (Mesbah et al., 1989).

$16 S$ rRNA gene amplification, sequencing and phylogenetic analysis. PCR amplification of the $16 \mathrm{~S}$ rRNA gene of strain 3CB-1 was performed with a GeneAmp PCR system 2400 as described previously (Song et al., 1998). The complete sequence of the 16S rRNA gene was obtained by using internal $16 \mathrm{~S}$ rRNA oligonucleotide sequencing primers $27 \mathrm{~F}$, 357F, 704F, 1242F, 1522R, 907R, 685R and 321R (Johnson, 1994b) and automated sequencer model ABI 373A (Perkin Elmer).

The rRNA gene sequences of strains in the genera Thauera and Azoarcus were obtained from the GenBank database and were aligned by using the PILEUP program of the Genetics Computer Group (GCG) software package (Devereux et al., 1984).

Phylogenetic analysis was carried out according to Kimura's two-parameter method (Kimura, 1980) and neighbour- 
Table 2. Degradation of aromatic compounds by strain $3 \mathrm{CB}-1$ under aerobic and denitrifying conditions

A dense cell suspension was incubated at $30^{\circ} \mathrm{C}$ for $3 \mathrm{~d}$ after feeding $100 \mu \mathrm{M}$ substrate. +, Complete loss of substrate; - , $<10 \%$ loss of substrate; ND, not determined.

\begin{tabular}{|lcc|}
\hline Substrate & Aerobic conditions & $\begin{array}{c}\text { Denitrifying } \\
\text { conditions }\end{array}$ \\
\hline Benzoate & + & + \\
2-Hydroxybenzoate & - & - \\
3-Hydroxybenzoate & + & + \\
4-Hydroxybenzoate & + & + \\
2-Fluorobenzoate & + & + \\
3-Fluorobenzoate & + & - \\
4-Fluorobenzoate & + & + \\
2-Chlorobenzoate & - & - \\
3-Chlorobenzoate & - & + \\
4-Chlorobenzoate & - & - \\
2-Bromobenzoate & - & - \\
3-Bromobenzoate & - & + \\
4-Bromobenzoate & - & + \\
3-Aminobenzoate & - & - \\
4-Aminobenzoate & - & + \\
Protocatechuate & ND & - \\
Phthalate & - & - \\
Phenol & - & - \\
2-Methylphenol & - & + \\
3-Methylphenol & - & + \\
4-Methylphenol & ND & \\
\hline
\end{tabular}

joining topology (Saitou \& Nei, 1987). The SEQBOOT program was used to obtain the confidence level for neighbourjoining analysis using a 100 bootstrapped data set (Felsenstein, 1985).

DNA-DNA hybridization. DNA-DNA hybridization was performed with ${ }^{3} \mathrm{H}$-TTP-labelled genomic DNAs of strains $3 \mathrm{CB}-1$ and $\mathrm{K} 172^{\mathrm{T}}$ by using the $\mathrm{S} 1$ nuclease method at a reannealing temperature of $68.7^{\circ} \mathrm{C}$ (Johnson, 1994a). DNA similarities of strain 3CB-1 were estimated with strains T1, $\mathrm{K} 172^{\mathrm{T}}, \mathrm{AX}^{\mathrm{T}}, \mathrm{VB}^{\mathrm{T}}{ }^{\mathrm{T}}$, Tol4 ${ }^{\mathrm{T}}$ and $\mathrm{KB} 740^{\mathrm{T}}$. Each DNA-DNA hybridization reaction was performed in duplicate and the mean value was taken as the DNA similarity value.

\section{RESULTS AND DISCUSSION}

\section{Morphological and phenotypic characterization}

Strain 3CB-1 was isolated from a river sediment after enrichment with 3-chlorobenzoate as carbon source and nitrate as electron acceptor (Häggblom \& Young, 1999). Cells are short rods of $3-3.75 \mu \mathrm{m}$ by $1-1.25 \mu \mathrm{m}$ (Fig. 1) and motile during early stages of growth. The flagella stain preparations show peritrichous insertion of the flagella (Fig. 1), a property in common with $T$. aromatica.

A phenotypic characterization of strain 3CB-1 in comparison with those of other strains in the genus Thauera is shown in Table 1. Strain 3CB-1 is catalaseand oxidase-positive and grows well on nutrient, brain-heart infusion and trypticase soy agar plates. It can tolerate $2 \%$ but not $5 \% \mathrm{NaCl}$ under denitrifying conditions. It grows best at $30^{\circ} \mathrm{C}$ and at $\mathrm{pH} 7 \cdot 5-8$. It cannot hydrolyse gelatin, starch or urea. The cells can grow with $\mathrm{O}_{2}, \mathrm{NO}_{3}^{-}$or $\mathrm{NO}_{2}^{-}$as electron acceptors in the presence of succinate, but not with $\mathrm{SO}_{4}^{2-}, \mathrm{SO}_{3}^{2-}, \mathrm{S}_{2} \mathrm{O}_{3}^{2-}$, $\mathrm{SeO}_{4}^{2-}$ nor $\mathrm{SeO}_{3}^{-}$.

Strain 3CB-1 can utilize 3-chlorobenzoate, 3-bromobenzoate and 3-iodobenzoate as growth substrate with nitrate as terminal electron acceptor (Häggblom \& Young, 1999). Additional growth substrates are listed in Table 1. The degradation of aromatic compounds by strain 3CB-1 under denitrifying or aerobic conditions is also listed in Table 2. Benzoate, benzyl alcohol, 3- and 4-hydroxybenzoate and caproate were used under denitrifying conditions, but in contrast to T. aromatica strains $\mathrm{K} 172^{\mathrm{T}}$ and $\mathrm{T} 1$, 4-hydroxyphenylacetate, propionate and toluene were not used as carbon sources.

Table 3. $16 \mathrm{~S}$ rRNA gene sequence similarities and genetic distances

\begin{tabular}{|c|c|c|c|c|c|c|c|c|c|c|c|c|}
\hline & 1 & 2 & 3 & 4 & 5 & 6 & 7 & 8 & 9 & 10 & 11 & 12 \\
\hline 1. Strain 3CB-1 (AF123264) & & $1 \cdot 36$ & $1 \cdot 51$ & $3 \cdot 37$ & $3 \cdot 44$ & $2 \cdot 98$ & $6 \cdot 57$ & $6 \cdot 65$ & $6 \cdot 90$ & $6 \cdot 24$ & $6 \cdot 73$ & $6 \cdot 32$ \\
\hline 2. T. aromatica T1 (U95176) & $98 \cdot 5$ & & $0 \cdot 15$ & 3.06 & $4 \cdot 23$ & $2 \cdot 44$ & $6 \cdot 57$ & $6 \cdot 65$ & $6 \cdot 58$ & $6 \cdot 24$ & $6 \cdot 41$ & $5 \cdot 76$ \\
\hline 3. T. aromatica $\mathrm{K} 172^{\mathrm{T}}(\mathrm{X} 77118)$ & $98 \cdot 5$ & $99 \cdot 7$ & & $3 \cdot 22$ & $4 \cdot 39$ & $2 \cdot 59$ & $6 \cdot 73$ & $6 \cdot 81$ & $6 \cdot 74$ & $6 \cdot 41$ & $6 \cdot 57$ & $5 \cdot 92$ \\
\hline 4. T. linaloolentis 47Lol ${ }^{\mathrm{T}}(\mathrm{AJ} 005816)$ & $97 \cdot 1$ & $97 \cdot 0$ & $97 \cdot 0$ & & $4 \cdot 40$ & $4 \cdot 72$ & $7 \cdot 14$ & $7 \cdot 22$ & $6 \cdot 73$ & $6 \cdot 40$ & $7 \cdot 47$ & $5 \cdot 59$ \\
\hline 5. T. terpenica $58 \mathrm{Eu}^{\mathrm{T}}(\mathrm{AJ} 005817)$ & $97 \cdot 1$ & $96 \cdot 0$ & $96 \cdot 0$ & $96 \cdot 0$ & & $4 \cdot 88$ & $6 \cdot 35$ & $6 \cdot 26$ & $6 \cdot 28$ & $5 \cdot 79$ & $6 \cdot 60$ & $5 \cdot 86$ \\
\hline 6. $T$. selenatis $\mathrm{AX}^{\mathrm{T}}(\mathrm{X} 68491)$ & $97 \cdot 2$ & $97 \cdot 5$ & $97 \cdot 4$ & $95 \cdot 4$ & $95 \cdot 2$ & & $6 \cdot 58$ & $6 \cdot 58$ & $6 \cdot 83$ & $6 \cdot 33$ & $6 \cdot 34$ & $6 \cdot 01$ \\
\hline 7. A. tolulyticus Tol4 $^{\mathrm{T}}$ (L33687) & $94 \cdot 2$ & $94 \cdot 0$ & $94 \cdot 0$ & $93 \cdot 4$ & $94 \cdot 0$ & $93 \cdot 6$ & & $0 \cdot 60$ & $1 \cdot 89$ & $1 \cdot 36$ & $3 \cdot 21$ & $4 \cdot 95$ \\
\hline 8. A. toluclasticus $\mathrm{MF} 63^{\mathrm{T}}$ (AF123077) & $93 \cdot 6$ & $93 \cdot 4$ & $93 \cdot 3$ & $93 \cdot 2$ & $93 \cdot 8$ & $93 \cdot 6$ & $99 \cdot 5$ & & 1.97 & $1 \cdot 51$ & $3 \cdot 13$ & $5 \cdot 19$ \\
\hline 9. A. toluvorans $\mathrm{Td} 21^{\mathrm{T}}$ (L33692) & $94 \cdot 0$ & $94 \cdot 0$ & $94 \cdot 0$ & $93 \cdot 8$ & $94 \cdot 1$ & $93 \cdot 3$ & $98 \cdot 3$ & $98 \cdot 2$ & & $0 \cdot 68$ & $4 \cdot 2$ & $5 \cdot 60$ \\
\hline 10. A. evansii KB740 ${ }^{\mathrm{T}}$ (X77679) & $94 \cdot 4$ & $94 \cdot 0$ & $94 \cdot 4$ & $94 \cdot 4$ & $94 \cdot 7$ & $93 \cdot 9$ & $98 \cdot 8$ & $97 \cdot 9$ & $99 \cdot 4$ & & $3 \cdot 68$ & $5 \cdot 03$ \\
\hline 11. A. anaerobius LuFRes $1^{\mathrm{T}}$ (Y14701) & $94 \cdot 0$ & $94 \cdot 2$ & $94 \cdot 2$ & $93 \cdot 5$ & $94 \cdot 0$ & $93 \cdot 9$ & $97 \cdot 1$ & $96 \cdot 4$ & $96 \cdot 2$ & $96 \cdot 4$ & & $5 \cdot 60$ \\
\hline 12. A. indigens $\mathrm{VB} 32^{\mathrm{T}}(\mathrm{AF} 011345)$ & $92 \cdot 6$ & $94 \cdot 3$ & $92 \cdot 8$ & $93 \cdot 0$ & $92 \cdot 7$ & $94 \cdot 2$ & $95 \cdot 5$ & $93 \cdot 5$ & $94 \cdot 9$ & $94 \cdot 3$ & $94 \cdot 5$ & \\
\hline
\end{tabular}




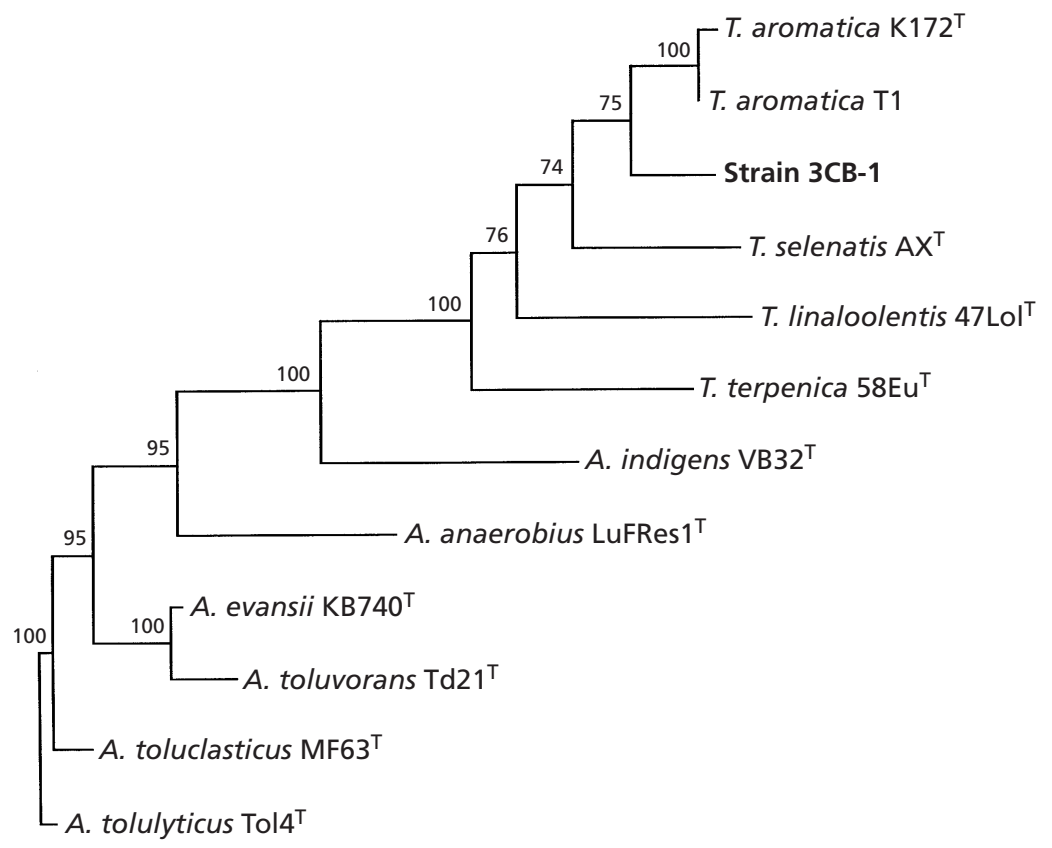

0.05
Fig. 2. Phylogenetic relationship of strain 3CB-1 with species of the genera Azoarcus and Thauera of the $\beta$-subclass of Proteobacteria. To build the tree 1500 bases were used. Scale bar represents $5 \mathrm{nt}$ substitutions per $100 \mathrm{nt}$.
Table 4. Genomic DNA similarities between strain 3CB-1 and strains of Azoarcus and Thauera

\begin{tabular}{|lc|}
\hline Strain & Similarity (\%) \\
\hline T. aromatica $\mathrm{K} 172^{\mathrm{T}}$ & $48 \cdot 6$ \\
T. aromatica $\mathrm{T} 1$ & $47 \cdot 5$ \\
T. selenatis $\mathrm{AX}$ & $21 \cdot 9$ \\
A. tolulyticus $\mathrm{Tol}^{\mathrm{T}}$ & $3 \cdot 1$ \\
A. evansii $\mathrm{KB} 740^{\mathrm{T}}$ & $2 \cdot 9$ \\
A. indigens $\mathrm{VB} 32^{\mathrm{T}}$ & $2 \cdot 7$ \\
\hline
\end{tabular}

\section{$16 \mathrm{~S}$ rRNA gene sequence analysis and phylogenetic} analysis

16S rRNA gene sequence analysis data and comparison with other strains of the genera Thauera and Azoarcus are listed in Table 3. Strain 3CB-1 is closely related to $T$. aromatica $\mathrm{K} 172^{\mathrm{T}}$ and $\mathrm{T} 1$ with $98.5 \%$ sequence homology, and has $97 \cdot 1 \%$ sequence similarity with $T$. linaloolentis and T. terpenica, and $97.2 \%$ similarity with type species $T$. selenatis. The phylogenetic analysis shows that strain 3CB-1 is located in the cluster of the genus Thauera as an individual taxon (Fig. 2).

\section{DNA-DNA hybridization}

Strain 3CB-1 has a $\mathrm{G}+\mathrm{C}$ content of $68.6 \mathrm{~mol} \%$. This value was used for the calculation of the proper reannealing temperature during DNA-DNA hybridization.
The genomic DNA homology values of strain 3CB-1 with members of the genera Thauera and Azoarcus are listed in Table 4. Strain 3CB-1 has about 48\% DNA homology with strains $\mathrm{K} 172^{\mathrm{T}}$ and $\mathrm{T} 1$ of $T$. aromatica and $21.9 \%$ genomic DNA homology with $T$. selenatis strain $\mathrm{AX}^{\mathrm{T}}$, but it does not have significant DNA homology with two species of the genus Azoarcus. In summary, on the basis of 16S rRNA gene sequence analysis and DNA-DNA hybridization, it can be concluded that strain 3CB-1 represents a new strain of the genus Thauera and may be considered a genomovar of $T$. aromatica.

\section{Determination of cellular fatty acid profiles}

The predominant fatty acids of the genera Thauera and Azoarcus are 10:0 3OH (5-8\%), 12:0 (4-8\%), $16: 1 \omega 7 c(42-53 \%), 16: 0(24-32 \%)$ and $18: 1(6-18 \%)$ after growth under denitrifying conditions. The cellular fatty acid profile of strain 3CB-1 compared with members of the genera Thauera and Azoarcus is shown in Table 5.

A dendrogram of Azoarcus and Thauera strains based on their fatty acid profiles is shown in Fig. 3. Thauera and Azoarcus are well differentiated at a Euclidian distance of 8 units, with the exception of $T$. selenatis which clusters separately from other Thauera spp. One main difference is the presence of $12: 03 \mathrm{OH}$ in $T$. selenatis and the absence of this fatty acid in other strains (Table 5). Strain 3CB-1 is included in the $T$. aromatica group, but not with $T$. selenatis. Thus, strain 3CB-1 can be considered as closely related to $T$. aromatica on the basis of the cellular fatty acid analysis. 
Table 5. Fatty acid composition of strains of Thauera and Azoarcus

Cells were cultivated with $10 \mathrm{mM}$ succinate and $30 \mathrm{mM}$ nitrate under anaerobic conditions for $24 \mathrm{~h}$ at $30^{\circ} \mathrm{C}$. T. selenatis was cultivated in the same denitrifying medium with addition of fivefold vitamin solution.

\begin{tabular}{|c|c|c|c|c|c|c|c|c|c|c|}
\hline \multirow[t]{2}{*}{ Strain } & \multicolumn{10}{|c|}{ Percentage of total fatty acids } \\
\hline & $10: 0$ & $\begin{array}{l}10: 0 \\
30 H\end{array}$ & $12: 0$ & $\begin{array}{l}12: 0 \\
30 H\end{array}$ & $14: 0$ & $16: 1 \omega 7 c$ & $16: 1 \omega 5 c$ & $16: 0$ & $\begin{array}{l}17: 0 \\
\text { cyclo }\end{array}$ & $\begin{array}{l}18: 1 \omega 7 c / \\
\omega 9 t / \omega 12 t\end{array}$ \\
\hline Strain 3CB-1 & $0 \cdot 0$ & $5 \cdot 5$ & $5 \cdot 5$ & $0 \cdot 0$ & $0 \cdot 0$ & $45 \cdot 7$ & $0 \cdot 5$ & $28 \cdot 7$ & $0 \cdot 7$ & $13 \cdot 4$ \\
\hline T. aromatica $\mathrm{K} 172^{\mathrm{T}}$ & $0 \cdot 0$ & $5 \cdot 5$ & $5 \cdot 7$ & $0 \cdot 0$ & $0 \cdot 0$ & $46 \cdot 2$ & $1 \cdot 3$ & $25 \cdot 1$ & $1 \cdot 7$ & $14 \cdot 5$ \\
\hline T. aromatica $\mathrm{T} 1$ & $0 \cdot 4$ & $6 \cdot 3$ & $6 \cdot 0$ & $0 \cdot 0$ & $0 \cdot 8$ & $42 \cdot 5$ & $0 \cdot 6$ & $31 \cdot 5$ & $1 \cdot 5$ & $10 \cdot 3$ \\
\hline T. selenatis $\mathrm{AX}^{\mathrm{T}}$ & $0 \cdot 0$ & $5 \cdot 0$ & $7 \cdot 8$ & $3 \cdot 6$ & $0 \cdot 0$ & $40 \cdot 9$ & $0 \cdot 0$ & $24 \cdot 6$ & $0 \cdot 0$ & $17 \cdot 6$ \\
\hline A. tolulyticus Tol4 ${ }^{\mathrm{T}}$ & $0 \cdot 6$ & $6 \cdot 6$ & $7 \cdot 1$ & $0 \cdot 0$ & $0 \cdot 8$ & $52 \cdot 7$ & $0 \cdot 5$ & $25 \cdot 4$ & $0 \cdot 0$ & $6 \cdot 8$ \\
\hline A. toluvorans $\mathrm{Td} 21^{\mathrm{T}}$ & $0 \cdot 5$ & $3 \cdot 1$ & $4 \cdot 7$ & $0 \cdot 0$ & $0 \cdot 8$ & $51 \cdot 0$ & $0 \cdot 0$ & $29 \cdot 7$ & $0 \cdot 0$ & $10 \cdot 3$ \\
\hline A. toluclasticus $\mathrm{MF} 63^{\mathrm{T}}$ & $0 \cdot 5$ & $5 \cdot 5$ & $5 \cdot 6$ & $0 \cdot 0$ & $0 \cdot 4$ & $51 \cdot 8$ & $0 \cdot 8$ & $25 \cdot 6$ & $0 \cdot 0$ & $9 \cdot 3$ \\
\hline A. evansii $\mathrm{KB} 740^{\mathrm{T}}$ & $0 \cdot 8$ & $8 \cdot 0$ & $6 \cdot 9$ & $0 \cdot 0$ & $0 \cdot 8$ & $46 \cdot 9$ & $0 \cdot 5$ & $27 \cdot 4$ & $0 \cdot 0$ & $8 \cdot 2$ \\
\hline
\end{tabular}

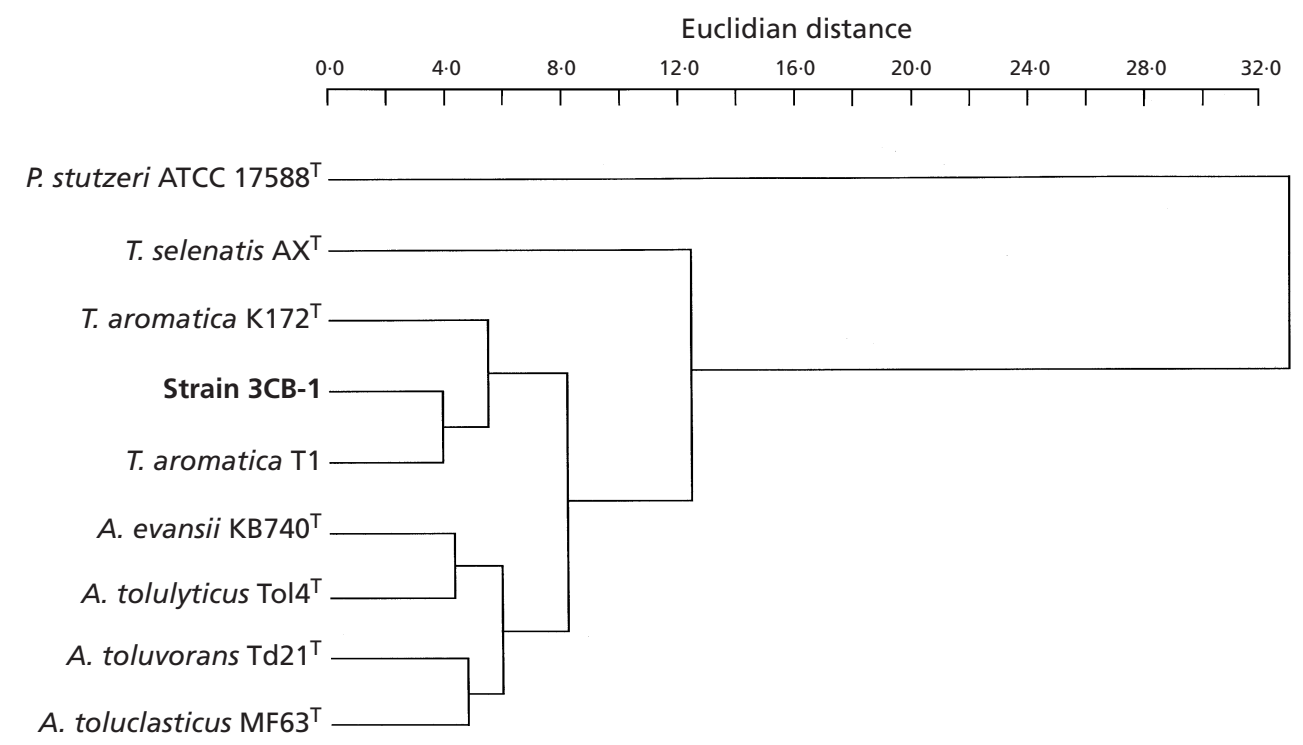

Fig. 3. Dendrogram of Azoarcus and Thauera strains based on cellular fatty acids analysis with Pseudomonas stutzeri as an outgroup. Strains were grown with $10 \mathrm{mM}$ succinate and $30 \mathrm{mM}$ nitrate for $24 \mathrm{~h}$ under denitrifying conditions. $T$. selenatis was grown in the same medium with a fivefold greater concentration of vitamins.

During extended incubation of strain 3CB-1, a marked shift in the fatty acid profile was observed. As the cells reached the exponential growth phase, a small amount of 17:0 cyclo fatty acid was produced (Fig. 4). During stationary phase, the amount of 17:0 cyclo increased with a stoichiometric reduction in the amount of 16: $1 \omega 7 c$. Similar production of cyclic fatty acids has been observed in other strains of the genus Thauera (data not shown) and other bacteria (Vibrio cholerae, Arthrobacter protophormiae, Pseudomonas aureofaciens and Pseudomonas fluorescens) during stationary phase or stress conditions (Guckert et al., 1986; Kieft et al., 1994, 1997).

\section{Description of Thauera aromatica genomovar chlorobenzoica}

Thauera aromatica genomovar chlorobenzoica (chlor.o.ben.zo'i.ca. M.L. adj. chloro pertaining to chlorine, from Gr. adj. chloros pale green; M.L. adj. benzoicus pertaining to benzoic acid; M.L. fem. adj. chlorobenzoica indicating the ability to utilize chlorobenzoic acid).

Gram-negative short rod, 3-3.7 $\mu \mathrm{m}$ when grown on MR2A aerobically for $24 \mathrm{~h}$ at $30^{\circ} \mathrm{C}$. Motile by peritrichous flagella during early stages of growth. Oxidase- and catalase-positive. Optimum temperature 


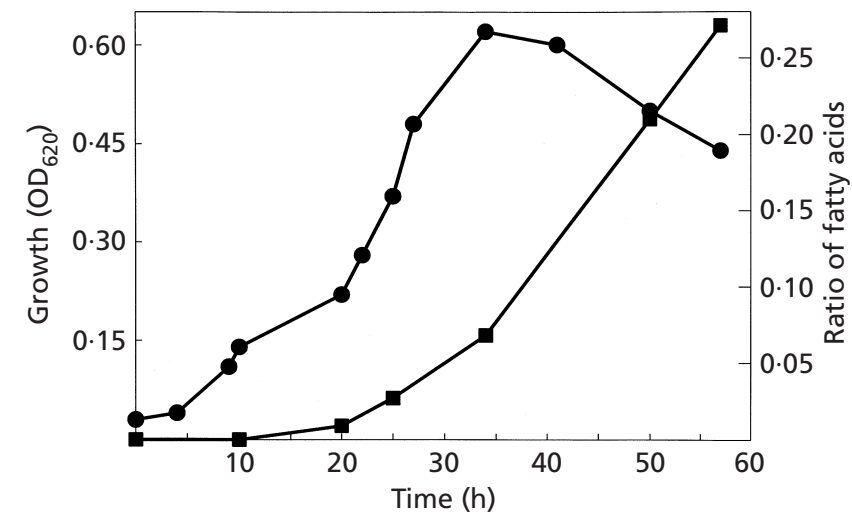

Fig. 4. Growth of strain $3 \mathrm{CB}-1$ (O) and changes in the ratio of methylene-hexadecanoic acid (17:0 cyclo) and cis-9-hexadecenoic acid $(16: 1 \omega 7 c)(\boldsymbol{\square})$ during prolonged incubation.

$30{ }^{\circ} \mathrm{C}$, optimum $\mathrm{pH} 7 \cdot 5-8$. Nitrate, nitrite and oxygen used as terminal electron acceptors. 3-Chlorobenzoate, 3-bromobenzoate and 3-iodobenzoate utilized as growth substrates under denitrifying conditions. Benzoate, 3- and 4-hydroxybenzoate, and 2- and 4fluorobenzoate utilized under both aerobic and anaerobic conditions. Benzyl alcohol, caproate, 3-aminobenzoate, protocatechuate, and 3-and 4-methylphenol used only under denitrifying conditions. Tolerates $2 \%$ $\mathrm{NaCl}$ under denitrifying conditions. No hydrolysis of gelatin, starch or urea. The predominant fatty acids are cis-9-hexadecenoic acid $(16: 1 \omega 7 c)$, hexadecanoic acid (16:0), octadecanoic acid (18:0), octadecenoic acid (18:1), 3-hydroxydecanoic acid $(10: 03 \mathrm{OH})$ and dodecanoic acid (12:0). During prolonged incubation under denitrifying conditions, the relative proportion of methylene-hexadecanoic acid (17:0 cyclo) increases with corresponding decrease in cis-9-hexadecenoic acid $(16: 1 \omega 7 c)$. On the basis of the cellular fatty acid analysis, 16S rRNA gene sequence analysis and DNA-DNA hybridization results, strain 3CB-1 belongs to Thauera aromatica as a genomovar, Thauera aromatica genomovar chlorobenzoica. It has been deposited in the American Type Culture Collection as strain ATCC 700723.

\section{ACKNOWLEDGEMENTS}

This study was supported in part by grant R822457 from the US Environmental Protection Agency.

\section{REFERENCES}

Anders, H., Kaetzke, A., Kämpfer, P., Ludwig, W. \& Fuchs, G. (1995). Taxonomic position of aromatic-degrading denitrifying pseudomonad strains K172 and KB740 and their description as new members of the genera Thauera, as Thauera aromatica sp. nov., and Azoarcus, as Azoarcus evansii sp. nov., respectively, members of the beta subclass of the Proteobacteria. Int $J$ Syst Bacteriol 45, 327-333.
Devereux, J., Haeberli, P. \& Smithies, O. (1984). A comprehensive set of sequence analysis programs for the VAX. Nucleic Acids Res 12, 387-395.

Evans, P. J., Mang, D. T., Kim, K. S. \& Young, L. Y. (1991). Anaerobic degradation of toluene by a denitrifying bacterium. Appl Environ Microbiol 57, 1139-1145.

Felsenstein, J. (1985). Confidence limits on phylogenies: an approach using the bootstrap. Evolution 39, 783-791.

Foss, S. \& Harder, J. (1998). Thauera linaloolentis sp. nov. and Thauera terpenica sp. nov., isolated on oxygen-containing monoterpenes (linalool, menthol, and eucalyptol) and nitrate. Syst Appl Microbiol 21, 365-373.

Gallus, C., Gorny, N., Ludwig, W. \& Schink, B. (1997). Anaerobic degradation of $\alpha$-resorcylate by a nitrate-reducing bacterium, Thanera aromatica strain AR-1. Syst Appl Microbiol 20, 540-544.

Guckert, J. B., Hood, M. A. \& White, D. C. (1986). Phospholipid ester-linked fatty acid profile changes during nutrient deprivation of Vibrio cholerae: increases in the trans/cis ratio and proportions of cyclopropyl fatty acids. Appl Environ Microbiol 52, 794-801.

Häggblom, M. M. \& Young, L. Y. (1999). Anaerobic degradation of 3-halobenozates by a denitrifying bacterium. Arch Microbiol 171, 230-236.

Häggblom, M. M., Rivera, M. D. \& Young, L. Y. (1993). Influence of alternative electron acceptors on the anaerobic biodegradability of chlorinated phenols and benzoic acids. Appl Environ Microbiol 59, 1162-1167.

Häggblom, M. M., Rivera, M. D. \& Young, L. Y. (1996). Anaerobic degradation of halogenated benzoic acids coupled to denitrification observed in a variety of sediment and soil samples. FEMS Microbiol Lett 144, 213-219.

Johnson, J. L. (1994a). Similarity analysis of DNAs. In Methods for General and Molecular Bacteriology, pp. 655-682. Edited by P. Gerhardt, R. G. E. Murray, W. A. Wood \& N. R. Krieg. Washington, DC: American Society for Microbiology.

Johnson, J. L. (1994b). Similarity analysis of rRNAs. In Methods for General and Molecular Bacteriology, pp. 683-700. Edited by P. Gerhardt, R. G. E. Murray, W. A. Wood \& N. R. Krieg. Washington, DC: American Society for Microbiology.

Kamal, V.S. \& Wyndham, R. C. (1990). Anaerobic phototrophic metabolism of 3-chlorobenzoate by Rhodopseudomonas palustris WS17. Appl Environ Microbiol 56, 3871-3873.

Kazumi, J., Häggblom, M. M. \& Young, L. Y. (1995). Diversity of anaerobic microbial processes in chlorobenzoate degradation: nitrate, iron, sulfate and carbonate as electron acceptors. Appl Microbiol Biotechnol 43, 929-936.

Kieft, T. L., Ringelberg, D. B. \& White, D. C. (1994). Changes in ester-linked phospholipid fatty acid profiles of subsurface bacteria during starvation and desiccation in a porous medium. Appl Environ Microbiol 60, 3292-3299.

Kieft, T. L., Wilch, E., O’Connor, K., Ringelberg, D. B. \& White, D. C. (1997). Survival and phospholipid fatty acid profiles of surface and subsurface bacteria in natural sediment microcosms. Appl Environ Microbiol 63, 1531-1542.

Kimura, M. (1980). A simple method for estimating evolutionary rate of base substitutions through comparative studies of nucleotide sequences. $J$ Mol Evol 16, 111-120.

Leifson, E. (1951). Staining, shape, and arrangement of bacterial flagella. J Bacteriol 62, 377-389. 
Macy, J. M., Rech, S., Auling, G., Dorsch, M., Stackebrandt, E. \& Sly, L. I. (1993). Thauera selenatis gen. nov., sp. nov., a member of the beta subclass of proteobacteria with a novel type of anaerobic respiration. Int J Syst Bacteriol 43, 135-142.

Mesbah, M., Premachandran, U. \& Whitman, W. B. (1989). Precise measurement of the $\mathrm{G}+\mathrm{C}$ content of deoxyribonucleic acid by high-performance liquid chromatography. Int J Syst Bacteriol 39, 159-167.

Saitou, N. \& Nei, M. (1987). The neighbor-joining method: a new method for reconstructing phylogenetic trees. Mol Biol Evol 4, 406-425.

Smibert, R. M. \& Krieg, N. R. (1994). Phenotypic characterization. In Methods for General and Molecular Bacteriology, pp. 607-654. Edited by P. Gerhardt, R. G. E. Murray, W. A. Wood \& N. R. Krieg. Washington, DC: American Society for Microbiology.
Song, B., Young, L. Y. \& Palleroni, N. J. (1998). Identification of denitrifier strain $\mathrm{T} 1$ as Thauera aromatica and proposal for emendation of the genus Thauera definition. Int J Syst Bacteriol 48, 889-894.

Song, B., Häggblom, M. M., Zhou, J., Tiedje, J. M. \& Palleroni, N. J. (1999). Taxonomic characterization of denitrifying bacteria that degrade aromatic compounds and description of Azoarcus toluvorans sp. nov. and Azoarcus toluclasticus sp. nov. Int J Syst Bacteriol 49, 1129-1140.

Tschech, A. \& Fuchs, G. (1987). Anaerobic degradation of phenol by pure cultures of newly isolated denitrifying pseudomonads. Arch Microbiol 148, 213-217.

van der Woude, B. J., De Boer, M., van der Put, N. M. J., van der Geld, F. M., Prins, R. A. \& Gottschal, J. C. (1994). Anaerobic degradation of halogenated benzoic acids by phototrophic bacteria. FEMS Microbiol Lett 119, 199-207. 